\title{
Stage Gate Decision making: a scoping review of Technology Strategic Selection Criteria for Early Stage Projects
}

\author{
Leonidas Aristodemou, \\ Innovation and Intellectual Property Management (IIPM) Lab, Centre for Technology Management \\ (CTM), Institute for Manufacturing (IfM), Department of Engineering, University of Cambridge
}

The Alan Turing Institute, London

Dr. Frank Tietze,

Innovation and Intellectual Property Management (IIPM) Lab, Centre for Technology Management (CTM), Institute for Manufacturing (IfM), Department of Engineering, University of Cambridge

Matthew Shaw,

Teneo Consulting, London

\begin{abstract}
Innovation is a hybrid concept that has evolved over time and adapts itself to changing condition. It plays a major role in the growth and economic competitiveness of firms, and consequently, firms invest in innovation to build knowledge and thus increase competitive advantage. Front End of Innovation (FEI) projects, and in particular technology development projects, are therefore a fundamental component of innovation and a crucial factor in developing new competitive advantage. To effectively and objectively manage and evaluate these early stage technology projects, which are by nature uncertain, a number of firms deploy some form of stage gate processes, utilizing strategic decision criteria. Via a descriptive scoping literature review, we identify 46 articles, which contain 473 uniquely identified strategic selection criteria that can fit in 9 categories. We find that technical feasibility is the most frequently occurring unique selection criteria, whereas the market category is the largest category by size of unique individual criteria with $23.3 \%$ of the share total. In this research, we contribute to the on-going discussion about early stage technology projects and their effective evaluation using strategic technology selection criteria. The summary of criteria provided with definitions may serve as guidelines for technology and innovation managers.
\end{abstract}

Index Terms - Early Stage Technology, Front End Innovation, Innovation management, Stage Gate, Strategic Decision Making, Technology Selection Criteria

\section{INTRODUCTION}

IN a time of rapidly changing technologies, shrinking product lifecycles and growing international competitiveness, it is increasingly important for firms to create, and maintain, competitive advantage [1], [2]. Innovation is a hybrid concept that has evolved over time and adapts itself to changing conditions [3]. It plays a major role in the growth and economic competitiveness of companies, industries and countries [4].

Innovation can also be defined as improvements in technology and better methods or ways of doing things, regardless of whether the new ideas are embodied in products, processes or services[5]-[9]. Fagerberg [3] argues that the function of innovation is to introduce novel knowledge into the economic sphere. Knowledge is considered an economic driver and a knowledge-based economy is defined as an economy directly based on the production, distribution and use of knowledge [10]. In addition, this knowledge-driven economy is at the heart of the technological era, which affects the innovation process as it strengthens the growth of all economies and sustainability paths [11], [12]. The increasing importance of knowledge as an economic driver has major implications for innovation management, which is a key determinant of competitiveness. Consequently, companies invest in innovation 
to build knowledge and thus increase competitive advantage. Innovation management can be articulated as a process, comprising the front end of innovation (FEI), new product development (NPD) and commercialisation [13], [14]. Formalised processes, such as NPD and commercialisation are well-documented [15]. On the contrary, processes within FEI remain unclear [16], [17].

The FEI, known as the "fuzzy front end" (FFE), is uncertain and highly ambiguous. No clear, universally-agreed definition for the FEI exists within the literature [18]. In this research, we adopt a hybrid definition: FEI is the period of development between idea generation and the go/no-go decision that leads to a formalised NPD process, such as Stage Gate [16]-[18]. Effectively managing the FEI is difficult [16]; projects and project teams are new and less defined than the later stages. This often leads to poor management and lack of creative solutions [18], [19]. Kim et al. [21] argue that more formalised processes in the FEI will facilitate a higher success rate in innovation projects. This formalisation of the FEI may occur through the use of strategic selection criteria to evaluate technology project decisions within technology development processes [14].

We define early stage technology projects as technology projects at the FEI, which either originate from an idea-driven or opportunity driven process or are in-sourced from outside the firm's boundaries, and include fundamental research, science or technology platform projects that lead to a diversity of developments. These projects are a directed effort at developing new knowledge, new technology, technical capability, skills and artefacts, that in turn will facilitate platform development [21]-[24]. This is similar to the definition by Cooper [15].

To effectively and objectively manage and evaluate these early stage technology projects, which are by nature uncertain, firms deploy a number of different models [17], [19], [25]-[30]. The debate of which model is more efficient and effective is ongoing both in academia and industry [31]-[36]. A number of these models and the on-going debate focus on how structured and formal this process is. In this research, we focus on the stage gate process particularly, which is a formalised process, to identify the strategic decision criteria of evaluating early stage technology projects [37]. The rational is that the stage gate process resembles the decision making process, with a gathering of information stage, and an evaluation gate of information relative to different strategic selection criteria, which leads to a decision [38]-[46].

Via a descriptive scoping literature review, we contribute to the on-going discussion about early stage technology projects and their effective evaluation using technology selection criteria. We identify 46 articles, which contain 473 uniquely identified strategic selection criteria that can fit in 9 categories. We provide a comprehensive summary of technology selection criteria with their definitions, acting as guidelines for technology and innovation managers. Section 2 defines the Technology Development Process. This is followed by Section
3 that describes the review methodology. Section 4 presents the bibliographic analysis results, followed by section 5 , which presents the analysis and discussion for the technology selection criteria. Section 6 concludes the paper with the key findings.

\section{Technology DeVelopment PROCESS}

The process for managing technology development, and a structured review procedure in the form of a technology stage gate, is supported by the propositions by Cooper [15], who argues that technology development projects are the foundation platforms for new opportunities and require a separate process to be managed, which he defines as the technology development process. He points that these particular projects, are rare, fragile and unique, identifying the problem that these knowledge-build projects are mismanaged, and proposes the technology stage gate model to manage, similar to the arguments by [14].

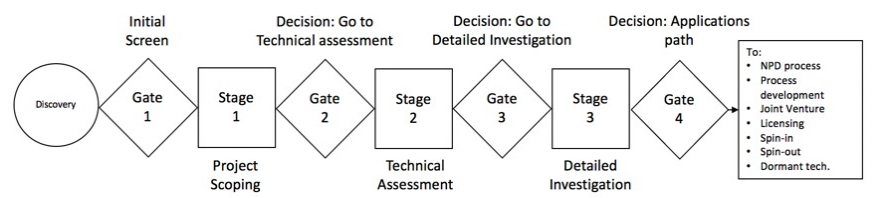

Fig. 1 Technology Development Process, defined by Cooper (2006)

The technology stage gate model consists of three stages and four gates and fuels the front end of innovation. The three stages consist of project scoping, technical assessment and detailed investigation. The four decision gates have different characteristics and consist of initial screening, go to technical assessment, go to detailed investigation, and the applications path (Fig. 1). This is similar to the work by Phaal [47], [48], with the transition model of industrial emergence, that within the innovation funnel there are transitions from discovery to science to technology to product development. Cooper [15] also argues that tailored strategic selection criteria should be used to evaluate these technology projects at the decision gates, which are guarded by gatekeepers ensuring the information is collected through a number of scoring techniques [26], [37], [49], [50]. Fig. 2 shows the stage gate process and how information is evaluated for an informed decision to be taken. Within the stage, there are information gathering activities, which lead to an integrated analysis of that information, resulting in deliverables. These deliverables act as input to the gate, where there is an evaluation of information relative to a set of strategic technology selection criteria, to take an informed decision. Recent publications in this field have argued for hybrid models of agile-stage gates, and opportunities and challenges arising from them [51]-[53].

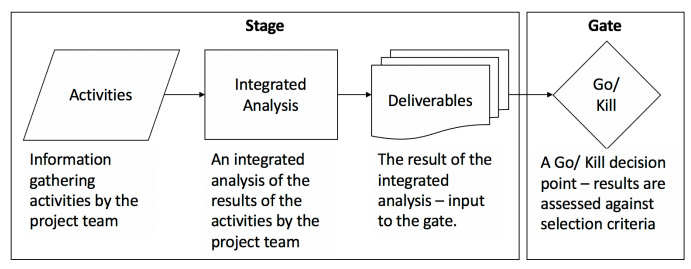

Fig. 2 Stage-gate decision process 


\section{Methodology}

The paper aims to summarize the existing work on strategic selection criteria, deployed within technology development processes and technology stage gate models, to evaluate early stage technology projects, at the front end of innovation. To carry out the literature review, a combined narrative, descriptive and scoping literature review approaches have been adopted [54], [55], to develop a research strategy [56]. The detailed search strategy is found in Appendix A. Fig. 3 shows the process flow for the comprehensive literature review.

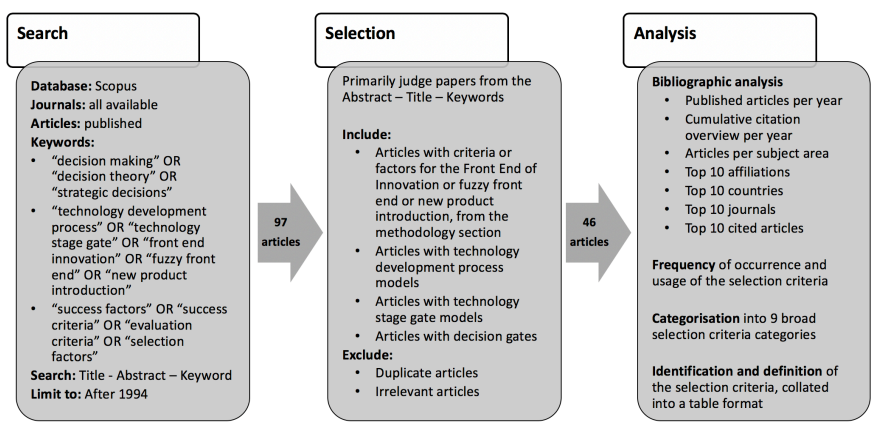

Fig. 3 Process flow of the comprehensive review

The articles on strategic selection criteria for early stage technology decisions were identified from Scopus database, to find the most relevant published articles or in press articles, in the English language. We search within the tittle, abstract and keywords for various terms such as "decision making", "decision theory" or "strategic decisions". The search is then narrowed to documents that also contain either in the title or the abstract or in the key words, the terms "technology development process", "technology stage gate", "stage gate", "decision gate", "innovation management", "front end innovation", "fuzzy front end", "early stage innovation", "front end process", "new product introduction", "technolog* innovation process", "innovation funnel". The search is further narrowed to documents that also contain either in the title or the abstract or in the key words, the terms "criteria", "factors", "success factors", "success criteria", "evaluation criteria", "evaluation factors", "selection criteria", "selection factors". In order to focus on recent literature, the search is limited to articles or in press articles published after the year 1994.

The search retrieved 97 articles, which after manual screening of removing duplicate or irrelevant articles 46 articles remained forming the core of this review. The purpose of presenting the results in detail is to provide the readers with the latest research and an overview on strategic selection criteria for early stage technology decisions. Results are in presented in section 5, with the first level focusing on the bibliographic information, followed by the analysis of the criteria categories and their definitions.

\section{BIBLIOGRAPHIC ANALYSIS RESULTS}

The first level of the analysis focuses on the review of the 46 articles' $\left(n_{1}\right)$ bibliographic information. Fig. 4 shows the number of articles published per year. The number of articles per year has been increasing since 1994, peaking in 2014 with 7 articles, which is an indication of increased interest in the field and the establishment of technology selection criteria. The average number of articles published per year is 1.84 and the median is 2. In addition, the rate of publication from 1994 to 2014 is 0.20 , whereas the rate of from 2014 to 2018 is 1.10 . Also, in 4 years, i.e. 1996, 1999, 2000, 2001, there are no articles identified, relative to the remaining 21 years.

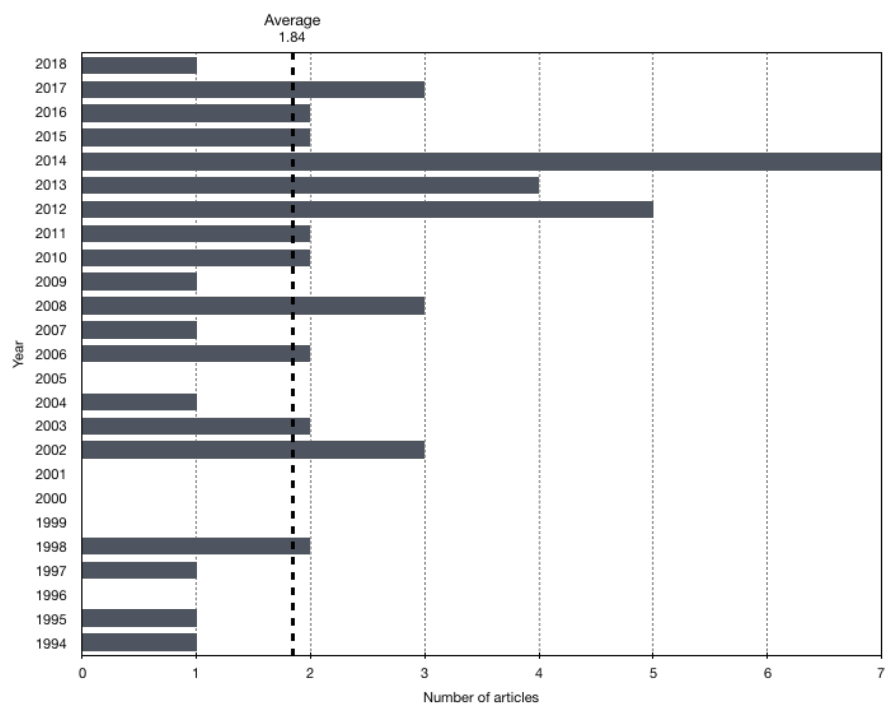

Fig. 4 Number of articles per year $\left(n_{1}=46\right)$ since 1994

The increase interest in the field, and how to make informed strategic decisions for technology projects is also evident within the percentage distribution within subject areas, with business, management and accounting (37\%) being the top area, followed by engineering $(31 \%)$ and computer science $(10 \%)$, as shown by Fig. 5 . Moreover, from Fig. 6 , we can observe that the number of citations per year has been increasing, with a steep increase after 2007, reaching a peak in 2015 and then remaining flat. There is a small deep in 2013 in the number of citations

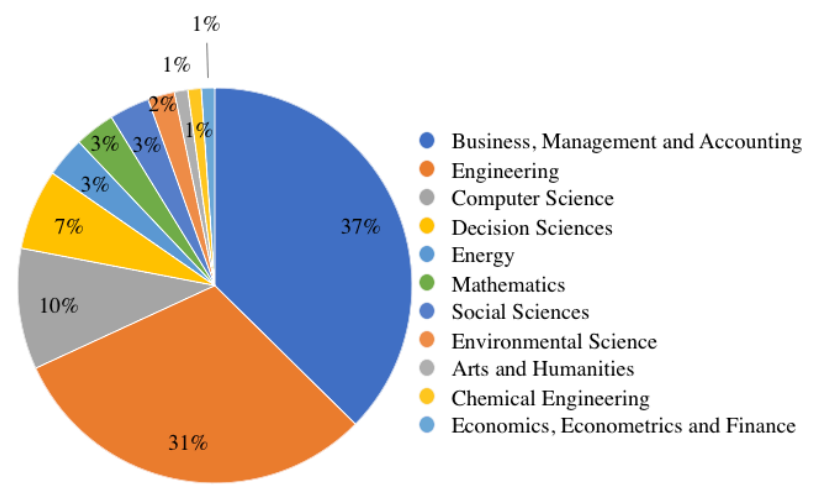

Fig. 5 Articles by subject area 


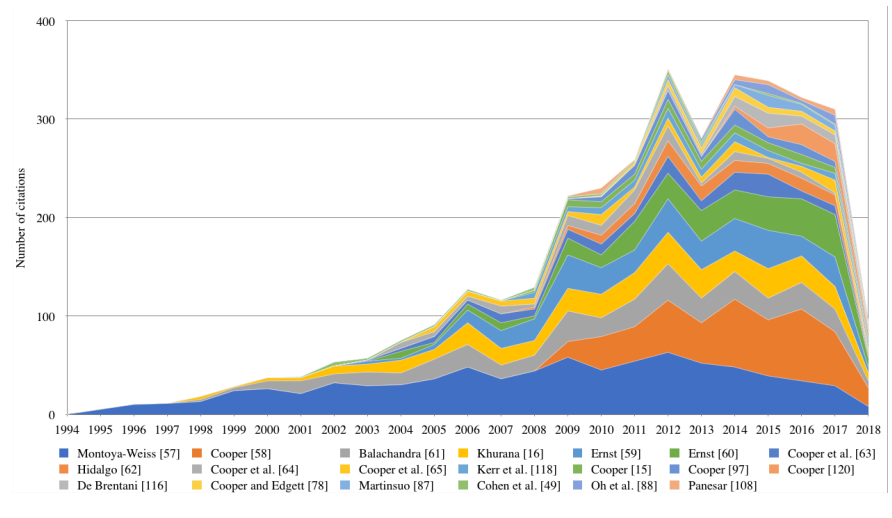

Fig.6 Citation overview per year for articles with 30+ citations

Table I shows the top 10 affiliations for the article authors. There have been a substantial number of papers published in McMaster University in Canada and this is reflected in Table II, where Canada is the second highest country. The University of Cambridge is the second highest institute in terms of affiliations and consequently the United Kingdom is the third highest country. Moreover, the U.S is the greatest contributor by country without a substantial contribution from one institution. This is likely due to an amalgamation of many different U.S. institutions given the fact that the top 10 institutions only account for $37 \%$ of the share total of the articles.

\section{Table I}

Top 10 Affiliations (n1 $=46$ articles, $\mathrm{n} 2=110$ observations)

\begin{tabular}{lll}
\hline \hline Affiliation & $\begin{array}{l}\text { No. of } \\
\text { observations }\end{array}$ & $\begin{array}{l}\text { Share of } \\
\text { Total (\%) }\end{array}$ \\
\hline McMaster University & 9 & $8 \%$ \\
University of Cambridge & 6 & $5 \%$ \\
Pennsylvania State University & 5 & $5 \%$ \\
$\begin{array}{l}\text { McMaster University, DeGroote } \\
\text { School of Business }\end{array}$ & 5 & $5 \%$ \\
$\begin{array}{l}\text { Product Development Institute } \\
\text { Wissenschaftliche Hochschule fur }\end{array}$ & 3 & $3 \%$ \\
Unternehmensfuhrung & 3 & $3 \%$ \\
$\begin{array}{l}\text { Massachusetts Institute of } \\
\text { Technology }\end{array}$ & 3 & $3 \%$ \\
$\begin{array}{l}\text { Product Development Institute Inc, } \\
\text { Canada }\end{array}$ & 3 & $3 \%$ \\
M. G. de Groote School of Business & 2 & $2 \%$ \\
Product Development Institute & 2 & $37 \%$ \\
\hline Total & 41 & \\
\hline \hline
\end{tabular}

Note: Articles with 1 or more affiliations are multi-counted

Table II shows the top 10 countries, where the article affiliations are. From Table II, it is also evident that European countries feature heavily with Sweden, Germany, France, Belgium and Spain all within the top 10, with $38 \%$ of the share total, which is similar to $39 \%$ accounted by North America (United States and Canada). Moreover, the top 10 countries account for $87 \%$ of the share total, indicating that these countries represent the majority of articles identified in the review, and the rest $13 \%$ is dispersed within other countries.

\section{Table II}

Top 10 countries ( $\mathrm{n}_{1}=46$ articles, $\mathrm{n}_{2}=61$ observations

\begin{tabular}{lll}
\hline \hline Country & $\begin{array}{l}\text { No. of } \\
\text { observations }\end{array}$ & $\begin{array}{l}\text { Share of } \\
\text { Total (\%) }\end{array}$ \\
\hline United States & 14 & $23 \%$ \\
Canada & 10 & $16 \%$ \\
United Kingdom & 7 & $11 \%$ \\
Sweden & 6 & $10 \%$ \\
Germany & 5 & $8 \%$ \\
South Korea & 3 & $5 \%$ \\
Belgium & 2 & $3 \%$ \\
Brazil & 2 & $3 \%$ \\
France & 2 & $3 \%$ \\
Spain & 2 & $3 \%$ \\
\hline Total & 53 & $87 \%$ \\
\hline \hline
\end{tabular}

Note: Articles with 1 or more countries are multi-counted

Table III shows the top 10 journals that the articles have been published in. Research Technology Management leads the field with 12 articles, which is $26 \%$ of the total articles. This is followed by the Journal of Product Innovation Management at $11 \%$ and the International Journal of Technology Intelligence and Planning at $7 \%$. The 24 articles have been published in total 24 journals. The top 10 journals account for $63 \%$ of the total number of articles showing that the research field is relatively focused; with the remaining $37 \%$ of articles being published in 14 journals.

Moreover, Table IV shows the top 10 most cited authors with the number of citations and the citation frequency. The citation frequency is the number of citations divided by the number of years that the article has been published. The most cited article is Montoya-Weiss [57], which although this article is the oldest published it still has a high citation frequency averaging at 33.13 per year. This is followed by Cooper [58], with 453 citations, which is the most frequently cited article with an average of 45.20 citations per year. In addition, 9 out of the top 10 cited articles have more than 100 cumulative citations, and out of those 9,7 have a citation frequency of more than 10 citations per year. Moreover, 4 out of the 10 most cited articles are authored by R.G. Cooper. 
Table III

Top 10 Journals ( $\mathrm{n} 1=46$ articles)

\begin{tabular}{lll}
\hline \hline Journal & $\begin{array}{l}\text { No. of } \\
\text { articles }\end{array}$ & $\begin{array}{l}\text { Share of } \\
\text { Total (\%) }\end{array}$ \\
\hline Research Technology Management & 12 & $26 \%$ \\
$\begin{array}{l}\text { Journal of Product Innovation } \\
\text { Management }\end{array}$ & 5 & $11 \%$ \\
$\begin{array}{l}\text { International Journal of Technology } \\
\text { Intelligence and Planning }\end{array}$ & 3 & $7 \%$ \\
R and D Management & 2 & $4 \%$ \\
Technovation & 2 & $4 \%$ \\
CIRP Annals Manufacturing Technology & 1 & $2 \%$ \\
Design Journal & 1 & $2 \%$ \\
Expert Systems with Applications & 1 & $2 \%$ \\
IEEE Engineering Management Review & 1 & $2 \%$ \\
IEEE Transactions on Engineering & 1 & $2 \%$ \\
Management & 29 & $63 \%$ \\
\hline Total & & \\
\hline \hline
\end{tabular}

Note: The 46 articles have been published in 24 journals

Table IV

Top 10 cited authors

\begin{tabular}{lll}
\hline \hline Author & Cited by & $\begin{array}{l}\text { Citation } \\
\text { Frequency }\end{array}$ \\
\hline Cooper [58] & 453 & 45.3 \\
Montoya-Weiss [57] & 795 & 33.1 \\
Ernst [59] & 339 & 21.2 \\
Ernst [60] & 296 & 19.7 \\
Balachandra [61] & 381 & 18.1 \\
Khurana [16] & 348 & 17.4 \\
Hidalgo [62] & 105 & 10.5 \\
Cooper et al. [63] & 144 & 9.0 \\
Cooper et al. [64] & 104 & 6.5 \\
Cooper et al. [65] & 86 & 6.1 \\
\hline \hline
\end{tabular}

\section{TeChNOlogy StRATEgiC SELECTION CRITERIA}

The second level of the analysis focuses on the strategic technology selection criteria. Across the 46 articles reviewed, we identify the occurrence of 562 selection criteria, of which 473 are unique. For each article, we gather the following information: author, year, article title, journal, number of citations, aim of the article, the selection criteria and the selection criteria definition. The 473 unique selection criteria are then analysed according to their frequency of occurrence and when they appear in the literature. This is followed by the grouping into 9 broad categories and the identification of each selection criterion definition.

Table V shows the appearance in the literature of the top 5 uniquely identified criteria before 2010, after 2010, and if they are in constant use. The most frequently occurring technology selection criterion, is technical feasibility with 9 occurrences in the 46 articles, followed by market attractiveness with 8 occurrences and then competitive advantage and strategic alignment, which both having 6 occurrences. The analysis of Table $\mathrm{V}$ describes when they appear in the literature: old (in use before 2010), new (in use after 2010), and constant (before and after 2010). The year 2010 is chosen because it has the highest frequency per year for all broad categories, as shown in Fig. 7. Constant appearance selection criteria include market attractiveness with 8 appearances, and strategic alignment with 6 appearances. Constant use criteria also include expected profitability, commercialisation and intellectual property with 2 appearances each. It is evident that constant use criteria fall within the Market, Strategy and business, Profit and Leverage broad categories of criteria, as shown by Table VI.

\section{Table V}

Appearance in the literature of old, new or constantly used unique identified criteria

\begin{tabular}{|c|c|c|c|c|c|c|}
\hline & \multicolumn{2}{|c|}{$\begin{array}{l}\text { Old Criteria } \\
\qquad(<2010)\end{array}$} & \multicolumn{2}{|c|}{$\begin{array}{l}\text { New Criteria } \\
\qquad>2010)\end{array}$} & \multicolumn{2}{|l|}{$\begin{array}{l}\text { Constant use } \\
\text { (since 1994) }\end{array}$} \\
\hline 1 & $\begin{array}{l}\text { Competitive } \\
\text { advantage }\end{array}$ & 6 & $\begin{array}{l}\text { Technical } \\
\text { feasibility }\end{array}$ & 9 & $\begin{array}{l}\text { Market } \\
\text { attractiveness }\end{array}$ & 8 \\
\hline 2 & Strategic fit & 4 & $\begin{array}{l}\text { Project } \\
\text { management }\end{array}$ & 5 & $\begin{array}{l}\text { Strategic } \\
\text { alignment }\end{array}$ & 6 \\
\hline 3 & $\begin{array}{l}\text { Customer } \\
\text { needs } \\
\text { analysis }\end{array}$ & 3 & $\begin{array}{l}\text { Availability } \\
\text { of resources }\end{array}$ & 3 & Commercialization & 2 \\
\hline 4 & Financial & 3 & $\begin{array}{l}\text { Time to } \\
\text { market }\end{array}$ & 3 & $\begin{array}{l}\text { Expected } \\
\text { profitability }\end{array}$ & 2 \\
\hline 5 & $\begin{array}{l}\text { Market } \\
\text { maturity }\end{array}$ & 3 & Uncertainty & 3 & $\begin{array}{l}\text { Intellectual } \\
\text { Property }\end{array}$ & 2 \\
\hline
\end{tabular}

Note: The top 5 unique criteria per year category

Moreover, criteria appearing before 2010, include competitive advantage with 6 appearances, followed by strategic fit with 4 , and customer needs analysis, financial and market maturity with 3 appearances. Competitive advantage is the third most frequently used unique criteria. Old criteria belong to the Leverage, Strategy and Business, Market, and Profit broad categories. New criteria, appearing after 2010, include technical feasibility with 9 occurrences, and project management with 5 occurrences. New criteria fall within the Technology, Project management, Resourcing, and Market broad categories. From the above, we can see that the Market and Strategy and Business broad categories are in constant use, whereas there is a shift from the leverage and profit broad categories before 2010, to the technology and project 
management broad categories after 2010. It should be noted that although the new criteria are occurring more frequently in recent literature this does not mean that they did not originate from an earlier date.

Technical feasibility is the most frequently occurring selection criteria and under the appearance analysis in the literature, it is classified as a new criterion i.e. a majority of the occurrences occurred after 2010. This shows the impact technology is having in a whole number of industries at this present time [66]. Companies are having to make more decisions at the front end of innovation based upon whether they have the scope in their company to develop a complex technology or not i.e. is the project technically feasible.

Table VI clusters by inspection the 562 identified into 9 main categories. These categories have been defined similar to Cooper [15]. The largest selection criteria category is Market, the probability of commercial success, which has $23.3 \%$ of the total number of selection criteria, and followed by the Technology, the probability of technical success, which has $14.9 \%$ of the total share. This is due to the early stage need to reduce the high uncertainty surrounding the market, the commercialisation process and consumer behaviour, at the front end of innovation. The top 3 categories are concluded with the Profit category, the probability of reward, with a share of $12.8 \%$, and account for $51 \%$ of the total selection criteria identified in the 46 articles. This shows the importance of these three categories, when making technology decisions, and is an indication of the market pull vs. technology push effect, with profit being the driver [67]-[72].

\section{Table VI}

Main Selection Criteria Categories and Definition

\begin{tabular}{|c|c|c|c|}
\hline Main Criteria & Definition & No. & Share $(\%)$ \\
\hline Market & $\begin{array}{l}\text { Probability of commercial } \\
\text { success }\end{array}$ & 131 & $23.3 \%$ \\
\hline Technology & $\begin{array}{l}\text { Probability of technical } \\
\text { success }\end{array}$ & 84 & $14.9 \%$ \\
\hline Profit & Profitability of reward & 72 & $12.8 \%$ \\
\hline Leverage & $\begin{array}{l}\text { Probability of competitive } \\
\text { advantage }\end{array}$ & 66 & $11.7 \%$ \\
\hline $\begin{array}{l}\text { Strategy and } \\
\text { Business }\end{array}$ & $\begin{array}{l}\text { Probability of achieving } \\
\text { long term goals }\end{array}$ & 62 & $11.0 \%$ \\
\hline Other & Other & 58 & $10.3 \%$ \\
\hline $\begin{array}{l}\text { Project } \\
\text { Management }\end{array}$ & $\begin{array}{l}\text { Probability of } \\
\text { implementation success }\end{array}$ & 43 & $7.6 \%$ \\
\hline Resourcing & Probability of capability & 31 & $5.5 \%$ \\
\hline Legal/Regulatory & $\begin{array}{l}\text { Probability of legislative } \\
\text { requirements }\end{array}$ & 15 & $2.7 \%$ \\
\hline Total & & 562 & $100 \%$ \\
\hline
\end{tabular}

Fig. 7 shows the category frequency distribution per year. It is evident that the year 2010 had the highest frequency and since then the moving average is significantly higher than before. The cumulative frequency distribution, from Fig. 8 shows that the trend has been increasing over the years. The growth of the Market and Technology categories reinforces their importance and significance in the literature. The Technology category grows significantly from 2008, which is due to the realization of the importance of technology factors [66]. The fact that all the categories are increasing is further evidence for the interest in this field.

For each of the selection criteria categories a condensed table was assembled listing the selection criteria, definition and citation. There was substantial crossover of selection criteria across different articles either by direct repetition, by similar phrasing or by implicit meaning and consequently the definitions chosen were the most comprehensive. Table VII XIV show the technology selection criteria per category, in descending category size order, sorted alphabetically within the tables, together with their definitions. The other category is omitted.

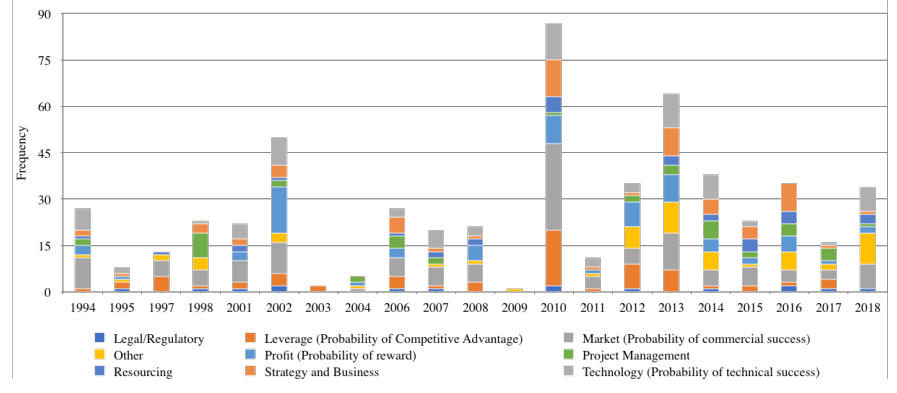

Fig. 7 Selection Criteria Categories Frequency distribution per year

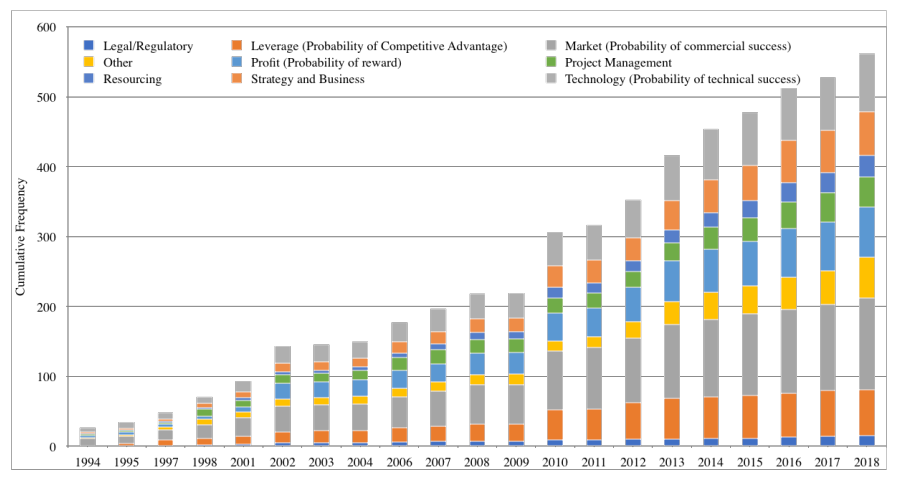

Fig. 8 Selection Criteria Categories Cumulative Frequency distribution per year 


\section{CONCLUSION}

To effectively manage and evaluate early stage technology projects, firms deploy stage gate processes, utilizing strategic decision criteria. In this paper, we identify via a scoping review 46 articles, which contain 473 uniquely identified strategic selection criteria that can fit in 9 broad categories. We find that technical feasibility is the most frequently occurring selection criteria, whereas the Market category is the largest category with $23.3 \%$ of the share total. There has been an increase in the interest to the field, shown by the increase in the number of articles in recent years, and the increase in the total number of citations of the papers. The majority of the articles (78\%) are in the fields of Business, Management and Accounting, Engineering, Computer science.

We hope this literature review would be helpful for research scholars and industrial users, in finding the latest research efforts pertaining to early stage technology selection criteria in a unified form. This ensures the development of the field in both a research and industrial context. We hope that researchers use this review as a consolidated effort to look for early stage technology project selection criteria, their emergence, development and usage throughout the literature. We also encourage industry professionals, technology and innovation managers, to use this consolidated review, to understand and evaluate the suitability and choice of technology selection criteria at the FEI, especially using the summary tables at the end of the articles.

Further research is required in this field to identify the significance of these technology selection criteria in project success and evaluate their suitability. It is important to understand the development of complementary methodologies and extensions of the stage-gate process [51], [52], [73], and understand other models utilized for early stage technology selection and their suitability [17], [74]. Further research should also be directed on the practical effectiveness and contextual factors of selection criteria, their uniqueness in measure project success, comparability of usefulness with advantages and disadvantages for each, and how this is reflected on their usage by industrial sector and firm size.
Table VII

Market Selection Criteria

\begin{tabular}{|c|c|c|}
\hline Selection Criteria & Definition & Citation \\
\hline Brand image & $\begin{array}{l}\text { What are the brand's attributes, design language, and } \\
\text { design principles [75] }\end{array}$ & {$[4],[75]$} \\
\hline $\begin{array}{l}\text { Commercial } \\
\text { applications } \\
\text { development skills }\end{array}$ & $\begin{array}{l}\text { The strength of the commercial applications } \\
\text { development skills in place at the company is } \\
\text { important for success [15] }\end{array}$ & {$[4],[15],[76]$} \\
\hline Commercialization & $\begin{array}{l}\text { Commercialization includes routes to market, key } \\
\text { partners, commercialization planning, } \\
\text { manufacturability and an understanding of whether } \\
\text { the end-users are satisfied [48], [77] }\end{array}$ & [4], [77] \\
\hline $\begin{array}{l}\text { Competitive } \\
\text { intensity }\end{array}$ & $\begin{array}{l}\text { This factor reflects the intensity of competition in the } \\
\text { marketplace in general and/or with respect to price, } \\
\text { margins earned by competitors [57], [78] }\end{array}$ & $\begin{array}{l}{[4],[15],[57],} \\
{[62],[64],} \\
{[76],[78]-} \\
{[81]}\end{array}$ \\
\hline $\begin{array}{l}\text { Concept field test } \\
\text { and demonstration }\end{array}$ & $\begin{array}{l}\text { Build and test pilot or field-scale unit to evaluate } \\
\text { performance against end-user expectations [77] }\end{array}$ & {$[77],[79]$} \\
\hline $\begin{array}{l}\text { Customer } \\
\text { dependency }\end{array}$ & $\begin{array}{l}\text { Customer dependency is when a company becomes } \\
\text { dependent on individual customers [82] }\end{array}$ & [82] \\
\hline Customer focus & $\begin{array}{l}\text { Focusing on the customer needs and employing a } \\
\text { market orientation throughout all departments [83] }\end{array}$ & $\begin{array}{l}{[49],[83]-} \\
{[85]}\end{array}$ \\
\hline Customer need & $\begin{array}{l}\text { Customer need is defined as the product's adaptation } \\
\text { to customer needs as well as knowledge of market and } \\
\text { customer characteristics }\end{array}$ & $\begin{array}{l}{[16],[79],} \\
{[80],[86]-} \\
{[89]}\end{array}$ \\
\hline Customer relations & $\begin{array}{l}\text { How important the project is to retaining customers } \\
\text { for the business [4] }\end{array}$ & [4] \\
\hline $\begin{array}{l}\text { Customer support } \\
\text { and feedback }\end{array}$ & $\begin{array}{l}\text { An important part of the value chain that will } \\
\text { determine the success of the project commercially is } \\
\text { the degree of customer support and feedback [90] }\end{array}$ & $\begin{array}{l}{[79],[89],} \\
{[90]}\end{array}$ \\
\hline $\begin{array}{l}\text { Effective } \\
\text { communication and } \\
\text { marketing }\end{array}$ & $\begin{array}{l}\text { Communication and dissemination of the marketing } \\
\text { plan ensure effective commercialization [91] }\end{array}$ & [91] \\
\hline Front End loading & $\begin{array}{l}\text { Due diligence, yield vital information for defining } \\
\text { product and project to proceed [83] }\end{array}$ & $\begin{array}{l}\text { [57], [83], } \\
{[84]}\end{array}$ \\
\hline Growth potential & $\begin{array}{l}\text { Growth potential is defined as the assessment of } \\
\text { innovations for their value creation potential [82] }\end{array}$ & {$[4],[82]$} \\
\hline Market analysis & $\begin{array}{l}\text { Market analysis refers to the firm's knowledge and } \\
\text { understanding of specific marketing and technical } \\
\text { aspects prior to product development e.g. target } \\
\text { market, customer needs, product concepts and } \\
\text { product specifications [57] }\end{array}$ & $\begin{array}{l}{[16],[57]} \\
{[61],[79]} \\
{[81],[92]}\end{array}$ \\
\hline $\begin{array}{l}\text { Market } \\
\text { attractiveness }\end{array}$ & $\begin{array}{l}\text { Defined according to market size and potential, } \\
\text { growth, margins earned, the competitive situation, the } \\
\text { entry barriers and the market accessibility [93], [94] }\end{array}$ & $\begin{array}{l}{[4],[58],[84],} \\
{[89],[93]-} \\
{[97]}\end{array}$ \\
\hline Market demand & $\begin{array}{l}\text { Market demand investigates whether there is a } \\
\text { demand and hence a market for the product [98] }\end{array}$ & {$[61],[98]$} \\
\hline $\begin{array}{l}\text { Market } \\
\text { development }\end{array}$ & $\begin{array}{l}\text { It establishes the 'newness' of the market to the } \\
\text { company [14] }\end{array}$ & {$[4],[14],[61]$} \\
\hline Market feasibility & $\begin{array}{l}\text { Market feasibility considers the probability of the } \\
\text { commercialization model and of the product benefits } \\
\text { to reach market requirements [99] }\end{array}$ & [99] \\
\hline Market growth & The rate of growth relative to other markets [78] & $\begin{array}{l}{[61],[62],} \\
{[64],[78],} \\
{[89]}\end{array}$ \\
\hline $\begin{array}{l}\text { Market intelligence } \\
\text { and knowledge }\end{array}$ & $\begin{array}{l}\text { Market size known to }+/-20 \% \text { and customer view } \\
\text { established by formal survey }[4]\end{array}$ & {$[4],[85]$} \\
\hline Market maturity & The state of the market: declining or growing. [15] & [4], [15], [76] \\
\hline Market need & An existing market with a consumer need. [15] & {$[4],[15],[76]$} \\
\hline Market potential & $\begin{array}{l}\text { It considers if there an apparent need and assesses the } \\
\text { potential for future market growth [14] }\end{array}$ & $\begin{array}{l}{[14],[48],} \\
{[57],[77],} \\
{[87]}\end{array}$ \\
\hline Market risks & $\begin{array}{l}\text { Market Risk involves technical and market } \\
\text { uncertainties that may result in losses to the company. } \\
\text { These may include uncontrollable factors such as } \\
\text { project delay, budget escalation, and nonconformity } \\
\text { to market demands [89] }\end{array}$ & [77], [89] \\
\hline Market size & $\begin{array}{l}\text { What is the size of the market: from } 100,000 \text { units to } \\
5,000 \text { units [4], [78] }\end{array}$ & $\begin{array}{l}{[4],[64],[78],} \\
{[89]}\end{array}$ \\
\hline Market uncertainty & $\begin{array}{l}\text { The probability of commercial success given the } \\
\text { uncertainties of the market [100] }\end{array}$ & $\begin{array}{l}{[87],[89]} \\
{[100]}\end{array}$ \\
\hline $\begin{array}{l}\text { Marketing } \\
\text { resources and skills }\end{array}$ & $\begin{array}{l}\text { To what extent does the marketing functional unit } \\
\text { support the project. [4], [61] }\end{array}$ & $\begin{array}{l}{[4],[61],[81],} \\
{[85],[89]}\end{array}$ \\
\hline $\begin{array}{l}\text { Marketing } \\
\text { synergies }\end{array}$ & $\begin{array}{l}\text { Marketing synergies represents the fit between the } \\
\text { needs of the project and the firm's resources and skills } \\
\text { with respect to the salesforce, distribution, } \\
\text { advertising, promotion, market research, and } \\
\text { customer service [57] }\end{array}$ & $\begin{array}{l}{[57],[64]} \\
{[84],[96]}\end{array}$ \\
\hline Product positioning & $\begin{array}{l}\text { The extent to which the positioning of the product at } \\
\text { launch will lead to market leadership [88] }\end{array}$ & [16] \\
\hline $\begin{array}{l}\text { Proficiency of } \\
\text { market related } \\
\text { activities } \\
\text { (distribution) }\end{array}$ & $\begin{array}{l}\text { This factor specifies proficiency of marketing } \\
\text { research, customer tests of prototypes or samples, test } \\
\text { markets/trial selling, service, advertising, } \\
\text { distribution, and market launch. [57] }\end{array}$ & $\begin{array}{l}{[4],[57],[80],} \\
{[90],[101]}\end{array}$ \\
\hline $\begin{array}{l}\text { Sales force } \\
\text { capability }\end{array}$ & What is the firm's ability to sell the product? [90] & $\begin{array}{l}{[4],[79],[89],} \\
{[90]}\end{array}$ \\
\hline Time to market & $\begin{array}{l}\text { Time to market considers the time span between the } \\
\text { start of the product development and its arrival at the } \\
\text { market [99] }\end{array}$ & $\begin{array}{l}{[57],[65]} \\
{[76],[99]} \\
{[101]}\end{array}$ \\
\hline
\end{tabular}


Table VIII

Technology Selection Criteria

\begin{tabular}{|c|c|c|}
\hline Selection Criteria & Definition & Citation \\
\hline $\begin{array}{l}\text { Existing production } \\
\text { capacity }\end{array}$ & $\begin{array}{l}\text { Having suitable production capacity and production } \\
\text { know-how }[80]\end{array}$ & {$[80]$} \\
\hline $\begin{array}{l}\text { Manufacturing } \\
\text { flexibility }\end{array}$ & $\begin{array}{l}\text { Product concept can have designed to repeated and } \\
\text { reproduced [89] }\end{array}$ & [89] \\
\hline Production quality & $\begin{array}{l}\text { A high-quality standard can especially be seen in the } \\
\text { avoidance of "teething troubles" or "bugs" [80] }\end{array}$ & {$[80]$} \\
\hline $\begin{array}{l}\text { Rate of technology } \\
\text { change }\end{array}$ & $\begin{array}{l}\text { How rapidly is the rate of technological change for } \\
\text { the project that is being pursued [78] }\end{array}$ & [78] \\
\hline $\begin{array}{l}\text { Technical } \\
\text { complexity }\end{array}$ & $\begin{array}{l}\text { How hard is it to see the solution for a given project } \\
\text { [15] }\end{array}$ & $\begin{array}{l}{[4], \quad[15],} \\
{[22],[64],} \\
{[76],[80],} \\
{[81],[89],} \\
{[100],} \\
{[102]}\end{array}$ \\
\hline Technical feasibility & $\begin{array}{l}\text { Technical feasibility considers the size of the } \\
\text { technical gap, the technical complexity (are there any } \\
\text { barriers), the familiarity of the technology to the } \\
\text { business, the technical track record on these types of } \\
\text { projects and the technical results to date [58] }\end{array}$ & $\begin{array}{l}{[22],[49],} \\
{[58],} \\
{[776],} \\
{[84],} \\
{[89],} \\
{[89],} \\
{[93],} \\
{[93],} \\
{[96]}\end{array}$ \\
\hline Technical gap & $\begin{array}{l}\text { It describes whether the development will require an } \\
\text { incremental improvement or a radical change [15] }\end{array}$ & $\begin{array}{l}{[4], \quad[15],} \\
{[64],[76]}\end{array}$ \\
\hline Technical impact & How much the technology impacts the business [103] & [103] \\
\hline Technical risk & $\begin{array}{l}\text { Determined by an analysis of the critical assumptions, } \\
\text { the amount of uncertainty, the newness of the market } \\
\text { and technology [95] }\end{array}$ & $\begin{array}{l}{[4], \quad[22],} \\
{[76],[90],} \\
{[94], \quad[95],} \\
{[102]-} \\
{[104]}\end{array}$ \\
\hline $\begin{array}{l}\text { Technical } \\
\text { uncertainty }\end{array}$ & $\begin{array}{l}\text { It is the insufficiency or imperfection of knowledge } \\
\text { or information critical to decision-making [4], [102] }\end{array}$ & $\begin{array}{l}{[4], \quad[48],} \\
{[64], \quad[87],} \\
{[89],} \\
{[102],} \\
{[105]}\end{array}$ \\
\hline $\begin{array}{l}\text { Technological } \\
\text { capability }\end{array}$ & $\begin{array}{l}\text { It is defined as whether or not new skills and } \\
\text { knowledge are required or whether the project is well } \\
\text { within the capability of the firm [4] }\end{array}$ & $\begin{array}{l}{[4], \quad[76],} \\
{[80],[90],} \\
{[104]}\end{array}$ \\
\hline $\begin{array}{l}\text { Technological or } \\
\text { manufacturing } \\
\text { synergies }\end{array}$ & $\begin{array}{l}\text { This represents a measure of the fit between the needs } \\
\text { of the project and the firm's resources and skills [57] }\end{array}$ & {$[57],[64]$} \\
\hline $\begin{array}{l}\text { Technological } \\
\text { proficiency }\end{array}$ & $\begin{array}{l}\text { Indicates proficiency of product development, in- } \\
\text { house testing of the product or prototype, trial/pilot } \\
\text { production, production start-up [57] }\end{array}$ & {$[57],[80]$} \\
\hline $\begin{array}{l}\text { Technology } \\
\text { development }\end{array}$ & $\begin{array}{l}\text { It covers whether the technology is new to the } \\
\text { company or already widely practiced [14] }\end{array}$ & [14] \\
\hline $\begin{array}{l}\text { Technology } \\
\text { elasticity }\end{array}$ & $\begin{array}{l}\text { Where does the technology sit in the technological 'S' } \\
\text { Curve [78] }\end{array}$ & [78] \\
\hline $\begin{array}{l}\text { Technology } \\
\text { importance }\end{array}$ & $\begin{array}{l}\text { It is a combination of the intensity of technology } \\
\text { usage on the one hand, and dependence on novel } \\
\text { technology through environmental pressure and } \\
\text { technological dynamism on the other hand [82] }\end{array}$ & [82] \\
\hline $\begin{array}{l}\text { Technology } \\
\text { potential }\end{array}$ & $\begin{array}{l}\text { Evaluate potential of the topic to create technological } \\
\text { change [77] }\end{array}$ & {$[14],[77]$} \\
\hline $\begin{array}{l}\text { Technology project } \\
\text { scope }\end{array}$ & $\begin{array}{l}\text { Develop technical project scope that addresses } \\
\text { barriers and proposes a research approach [77] }\end{array}$ & [77] \\
\hline $\begin{array}{l}\text { Technology } \\
\text { readiness levels }\end{array}$ & $\begin{array}{l}\text { It is type of measurement system used to assess the } \\
\text { maturity level of a particular technology [106] }\end{array}$ & [22], [103] \\
\hline $\begin{array}{l}\text { Technology skill } \\
\text { base }\end{array}$ & $\begin{array}{l}\text { It describes whether the technology is new to the } \\
\text { company or widely practiced [15] }\end{array}$ & $\begin{array}{l}{[4], \quad[15],} \\
{[80], \quad[89],} \\
{[94],} \\
{[100],} \\
{[103]}\end{array}$ \\
\hline
\end{tabular}

Table IX

Profit Selection Criteria

\begin{tabular}{|c|c|c|}
\hline Selection Criteria & "Definition & Citation \\
\hline $\begin{array}{l}\text { Contribution to } \\
\text { profitability }\end{array}$ & $\begin{array}{l}\text { It describes how much profit the project will } \\
\text { contribute to the company [15] }\end{array}$ & $\begin{array}{l}{[4], \quad[15],} \\
{[64],[65],} \\
{[76],[85]}\end{array}$ \\
\hline Cost & $\begin{array}{l}\text { Reflects project development cost, including } \\
\text { measures of production, R\&D, or marketing cost } \\
\text { overruns or expenditures [57] }\end{array}$ & $\begin{array}{l}{[57],[88],} \\
{[101]} \\
{[107]} \\
{[108]}\end{array}$ \\
\hline $\begin{array}{l}\text { Expected } \\
\text { commercial value } \\
\text { (ECV) }\end{array}$ & $\begin{array}{l}\text { It defines the various possible outcomes of the project } \\
\text { along with probabilities of each occurring. }\end{array}$ & [76], [96] \\
\hline $\begin{array}{l}\text { Financial business } \\
\text { analysis }\end{array}$ & $\begin{array}{l}\text { Reflects the proficiency of ongoing financial and } \\
\text { business analysis during development, prior to } \\
\text { commercialization and full-scale launch [57] }\end{array}$ & $\begin{array}{l}{[57],[79],} \\
{[104],} \\
{[109]}\end{array}$ \\
\hline $\begin{array}{l}\text { Financial } \\
\text { development }\end{array}$ & $\begin{array}{l}\text { It is defined as the knowledge of how much the start- } \\
\text { up cost, unit cost and other capital costs [14] }\end{array}$ & {$[14]$} \\
\hline Financial feasibility & $\begin{array}{l}\text { It is the ability of the product to be produced in a } \\
\text { profitable manner [ } 98]\end{array}$ & [98] \\
\hline Financial potential & $\begin{array}{l}\text { It is defined as the degree of product demand and the } \\
\text { amount of competition for that demand [14] }\end{array}$ & $\begin{array}{l}{[14],[22],} \\
{[62],[103]}\end{array}$ \\
\hline Financial return & $\begin{array}{l}\text { It considers the financial return of the product to the } \\
\text { business, including metrics such as return of } \\
\text { investment, payback period, internal rate of return } \\
\text { and net present value [99] }\end{array}$ & $\begin{array}{l}{[89],[99],} \\
{[109]}\end{array}$ \\
\hline $\begin{array}{l}\text { Flexible pricing } \\
\text { policy }\end{array}$ & $\begin{array}{l}\text { High flexibility in the setting of prices differentiates } \\
\text { between successful and unsuccessful innovators } \\
{[110]}\end{array}$ & [80] \\
\hline Innovation potential & $\begin{array}{l}\text { This is the beginning of a major new business or } \\
\text { many further applications and innovations [4] }\end{array}$ & {$[4],[107]$} \\
\hline $\begin{array}{l}\text { Internal rate of } \\
\text { return (IRR) }\end{array}$ & $\begin{array}{l}\text { It is a discount rate that makes the net present } \\
\text { value (NPV) of all cash flows from a particular } \\
\text { project equal to zero [111] }\end{array}$ & [64] \\
\hline $\begin{array}{l}\text { Learning and } \\
\text { growth }\end{array}$ & $\begin{array}{l}\text { Capability growth of the human resources, systems } \\
\text { and organizational processes [4] }\end{array}$ & {$[4]$} \\
\hline $\begin{array}{l}\text { Level of investment } \\
\text { required }\end{array}$ & $\begin{array}{l}\text { The amount of money required and where it is } \\
\text { sourced from [22] }\end{array}$ & {$[4],[22]$} \\
\hline $\begin{array}{l}\text { Net present value } \\
\text { (NPV) }\end{array}$ & A financial indicator of a projects potential [96] & $\begin{array}{l}{[4],[76],} \\
{[88],[96]}\end{array}$ \\
\hline Payback period & $\begin{array}{l}\text { The payback period is how quickly the project returns } \\
\text { the initial investment [15] }\end{array}$ & $\begin{array}{l}{[4], \quad[15],} \\
{[64],[76],} \\
{[85]}\end{array}$ \\
\hline $\begin{array}{l}\text { Return on } \\
\text { investment }\end{array}$ & $\begin{array}{l}\text { It measures the amount of return on an investment, } \\
\text { relative to the investment's cost [112] }\end{array}$ & $\begin{array}{l}{[4], \quad[75],} \\
{[76],[108]}\end{array}$ \\
\hline Risk vs. return & $\begin{array}{l}\text { Size of the financial opportunity; financial return } \\
\text { (NPV/ ECV/ IRR); productivity index; certainty of } \\
\text { financial estimates; level of risk and ability to address } \\
\text { risks [58] }\end{array}$ & $\begin{array}{l}{[58],[64],} \\
{[76],[84],} \\
{[89],[92],} \\
{[93],[95],} \\
{[96],[108]}\end{array}$ \\
\hline $\begin{array}{l}\text { Sales and profit } \\
\text { objectives }\end{array}$ & $\begin{array}{l}\text { Objectives include: expected revenue, number of } \\
\text { sales, gross profit margins }[85],[88]\end{array}$ & {$[85],[88]$} \\
\hline $\begin{array}{l}\text { Time to commercial } \\
\text { start up }\end{array}$ & $\begin{array}{l}\text { How long will it take to set up the project and develop } \\
\text { commercially [15] }\end{array}$ & {$[15],[64]$} \\
\hline User base growth & Contribution to user base growth $[88]$ & [88] \\
\hline
\end{tabular}


Table X

\section{Leverage Selection Criteria}

\begin{tabular}{|c|c|c|}
\hline Selection Criteria & Definition & Citation \\
\hline $\begin{array}{l}\text { Characteristics of } \\
\text { the product }\end{array}$ & $\begin{array}{l}\text { Product differentiation, sustainability of } \\
\text { competitive, technical challenge, uniqueness [4] }\end{array}$ & $\begin{array}{ll}{[4],} & {[48],} \\
{[64],} & {[78],} \\
{[98]} & \end{array}$ \\
\hline $\begin{array}{l}\text { Competitive } \\
\text { advantage }\end{array}$ & $\begin{array}{l}\text { It is the technological or business advantage } \\
\text { relative to the competition [49] }\end{array}$ & $\begin{array}{ll}{[4],} & {[49],} \\
{[77],} & {[84],} \\
{[89],} & {[93],} \\
{[104]} & \end{array}$ \\
\hline $\begin{array}{l}\text { Core competency } \\
\text { leverage }\end{array}$ & $\begin{array}{l}\text { Core competencies and strengths in: technology, } \\
\text { production, marketing, distribution [58] }\end{array}$ & $\begin{array}{l}{[58], \quad[78],} \\
{[88], \quad[89],} \\
{[93],[95]}\end{array}$ \\
\hline Durability & $\begin{array}{l}\text { It covers the length of the lifecycle and the } \\
\text { opportunity for incremental spin offs [15] }\end{array}$ & {$[4],[15],[76]$} \\
\hline Early to market & $\begin{array}{l}\text { Early entrance to market is a strong factor in the } \\
\text { success of the new product [110] }\end{array}$ & [61] \\
\hline Innovative product & $\begin{array}{l}\text { The innovativeness of the product can span from } \\
\text { incremental to radical [61] }\end{array}$ & {$[61],[88]$} \\
\hline $\begin{array}{l}\text { Inventor } \\
\text { circumstances }\end{array}$ & $\begin{array}{l}\text { How easy can the product be commercialized and } \\
\text { awareness of inventor to commercialization [81] }\end{array}$ & [81] \\
\hline $\begin{array}{l}\text { New product } \\
\text { portfolio } \\
\text { management }\end{array}$ & $\begin{array}{l}\text { The effectiveness in which an organization } \\
\text { manages its new products portfolio is often a key } \\
\text { determinant of competitive advantage [113] }\end{array}$ & $\begin{array}{l}{[83], \quad[109],} \\
{[114]}\end{array}$ \\
\hline Perceived value & $\begin{array}{l}\text { The merits a customer ascribes to a product or } \\
\text { service [115] }\end{array}$ & {$[61],[116]$} \\
\hline Platform for growth & Does it open up new product possibilities? [15] & {$[4],[15],[76]$} \\
\hline $\begin{array}{l}\text { Product competitive } \\
\text { advantage }\end{array}$ & $\begin{array}{l}\text { It includes: delivering unique customer benefits; } \\
\text { offering customer excellent value for money; } \\
\text { Differentiation of the product in the eyes of the } \\
\text { customer [58] }\end{array}$ & $\begin{array}{l}{[4], \quad[57],} \\
{[58], \quad[64],} \\
{[89], \quad[94]-} \\
{[96],[99]}\end{array}$ \\
\hline $\begin{array}{l}\text { Intellectual Property } \\
\text { (Proprietary } \\
\text { position) }\end{array}$ & $\begin{array}{l}\text { How well protected is the technology development } \\
\text { project through trade secrets, patents, raw material } \\
\text { access [15] }\end{array}$ & $\begin{array}{l}{[4],} \\
{[60],} \\
{[76],} \\
{[88],[104]}\end{array}$ \\
\hline $\begin{array}{l}\text { Rate of product } \\
\text { introduction }\end{array}$ & $\begin{array}{l}\text { It reflects the stage of life cycle of the product } \\
\text { category. }\end{array}$ & {$[61]$} \\
\hline $\begin{array}{l}\text { Unique customer } \\
\text { benefits }\end{array}$ & $\begin{array}{l}\text { When a product concept can deliver unique } \\
\text { customer benefits [89] }\end{array}$ & [89] \\
\hline User risk & $\begin{array}{l}\text { The degree to which the attributes of user } \\
\text { interaction with the product are known and the } \\
\text { degree to which design and performance } \\
\text { specifications are known [90] }\end{array}$ & [90] \\
\hline
\end{tabular}

Table XI

Strategy and Business Selection Criteria

\begin{tabular}{|c|c|c|}
\hline Selection Criteria & Definition & Citation \\
\hline $\begin{array}{l}\text { Business incentives } \\
\text { and risks }\end{array}$ & $\begin{array}{l}\text { They takes into consideration economic } \\
\text { attractiveness, key business issues, and } \\
\text { uncertainties [49] }\end{array}$ & [49] \\
\hline Business procedures & $\begin{array}{l}\text { The firm's business model, competitive advantage } \\
\text { and degree of integration [4] }\end{array}$ & {$[4],[75]$} \\
\hline Congruence & $\begin{array}{l}\text { A measure of how well the project fits with the } \\
\text { business strategy [15] }\end{array}$ & $\begin{array}{l}{[4],} \\
{[117]}\end{array}$ \\
\hline Innovation strategy & $\begin{array}{l}\text { The long term administrative commitment and } \\
\text { recourse allocation towards innovation efforts[ } 65]\end{array}$ & [114] \\
\hline $\begin{array}{l}\text { Organizational } \\
\text { commitment }\end{array}$ & People's motivation and commitment [99] & [99], [109] \\
\hline Patent analytics & $\begin{array}{l}\text { Patent analytics support informed strategic } \\
\text { decisions [118] }\end{array}$ & [118] \\
\hline Strategic alignment & $\begin{array}{l}\text { It considers the product alignment or its } \\
\text { contribution to corporate or business strategies, } \\
\text { objectives, goals and interests [99] }\end{array}$ & $\begin{array}{ll}{[4],} & {[16],} \\
{[22],} & {[63],} \\
{[79],} & {[89],} \\
{[93],} & {[95],} \\
{[96],[99]} & \end{array}$ \\
\hline Strategic approach & $\begin{array}{l}\text { Thinking strategically about your process } \\
\text { implementation is critical for managing } \\
\text { expectations and getting the buy-in you need [91] }\end{array}$ & [91] \\
\hline Strategic fit & $\begin{array}{l}\text { Strategic fit is the fit with the business strategy and } \\
\text { needs [49] }\end{array}$ & $\begin{array}{ll}{[4],} & {[49],} \\
{[57],} & {[63],} \\
{[76],} & {[77],} \\
{[84],} & {[87]-} \\
{[89],} & {[92],} \\
{[119]} & \end{array}$ \\
\hline Strategic focus & $\begin{array}{l}\text { High-level assessments regarding significant local } \\
\text { or international gaps [109] }\end{array}$ & [109] \\
\hline Strategic impact & $\begin{array}{l}\text { The extent to which the business' future depends } \\
\text { on the project }[15]\end{array}$ & {$[4],[15],[89]$} \\
\hline $\begin{array}{l}\text { Strategic } \\
\text { importance }\end{array}$ & $\begin{array}{l}\text { It considers to what extent does the success of the } \\
\text { company's overall strategy depend on the } \\
\text { particular program or project [58] }\end{array}$ & $\begin{array}{l}{[4],} \\
{[63]} \\
{[89]} \\
{[104]}\end{array}$ \\
\hline $\begin{array}{l}\text { Synergy with other } \\
\text { business units }\end{array}$ & $\begin{array}{l}\text { Synergy is defined as the extent that the project can } \\
\text { be applied to other business units [4] }\end{array}$ & {$[4],[15]$} \\
\hline $\begin{array}{l}\text { Technology } \\
\text { intelligence }\end{array}$ & $\begin{array}{l}\text { Technology intelligence supports informed } \\
\text { strategic decisions [118] }\end{array}$ & $\begin{array}{l}{[107],[109],} \\
{[118]}\end{array}$ \\
\hline $\begin{array}{l}\text { Top management } \\
\text { involvement }\end{array}$ & $\begin{array}{l}\text { The degree to which top management } \\
\text { demonstrates their strong and visible support [84] }\end{array}$ & $\begin{array}{l}{[4],} \\
{[84],} \\
{[120]}\end{array} \quad[117]$, \\
\hline Vision & $\begin{array}{l}\text { The vision is the aspirational direction for future } \\
\text { products [117] }\end{array}$ & $\begin{array}{l}{[75], \quad[109],} \\
{[117]}\end{array}$ \\
\hline
\end{tabular}


TABLE XII

Project Management Selection Criteria

\begin{tabular}{|c|c|c|}
\hline Selection Criteria & Definition & Citation \\
\hline $\begin{array}{l}\text { Cross functional } \\
\text { teams }\end{array}$ & $\begin{array}{l}\text { Cross functional teams are important because they } \\
\text { provide a wealth of experience and input across } \\
\text { many functional units [91] }\end{array}$ & $\begin{array}{ll}{[84],} & {[91],} \\
{[121]} & \end{array}$ \\
\hline $\begin{array}{l}\text { Defined roles and } \\
\text { responsibilities }\end{array}$ & $\begin{array}{l}\text { All parties involved have clearly defined roles and } \\
\text { responsibilities [91] }\end{array}$ & [16], [91] \\
\hline $\begin{array}{l}\text { Function } \\
\text { (execution) }\end{array}$ & $\begin{array}{l}\text { What is the nature of the deliverables: platform, } \\
\text { modular, or custom product? What are the unique } \\
\text { selling points and required number of Shelf } \\
\text { Keeping Units? What are their technical } \\
\text { requirements? [75] }\end{array}$ & [75] \\
\hline Holistic approach & $\begin{array}{l}\text { Clear success criteria - view of product innovation } \\
\text { as a business function [83] }\end{array}$ & [83] \\
\hline $\begin{array}{l}\text { Internal and external } \\
\text { communication }\end{array}$ & $\begin{array}{l}\text { The coordination and cooperation within the firm } \\
\text { and between firms and involves: communication } \\
\text { or information exchange between departments and } \\
\text { external firms, cross-functional participation on } \\
\text { projects and degree of interaction[57] }\end{array}$ & $\begin{array}{l}{[16],} \\
{[114]}\end{array}$ \\
\hline Killer variables & Are there any showstoppers [49] & $\begin{array}{l}{[49], \quad[64],} \\
{[92]}\end{array}$ \\
\hline $\begin{array}{l}\text { Knowledge } \\
\text { management }\end{array}$ & $\begin{array}{l}\text { The management of explicit and implicit } \\
\text { knowledge within organizations [114] }\end{array}$ & [77], [114] \\
\hline Leadership support & $\begin{array}{l}\text { Leadership team is strongly behind the initiative } \\
\text { then the chances of success will improve } \\
\text { dramatically [91] }\end{array}$ & [91] \\
\hline $\begin{array}{l}\text { Metrics and } \\
\text { accountability }\end{array}$ & You can't manage what you don't measure [83] & $\begin{array}{l}{[83]} \\
{[109]}\end{array}$ \\
\hline $\begin{array}{l}\text { NPD project meets } \\
\text { objectives }\end{array}$ & $\begin{array}{l}\text { Is the project on time and on budget and does it } \\
\text { meet all of its objectives [65] }\end{array}$ & [65] \\
\hline $\begin{array}{l}\text { Organizational } \\
\text { factors }\end{array}$ & $\begin{array}{l}\text { The organizational structure of the firm, } \\
\text { specifically with respect to the new product project } \\
\text { (i.e. teams). It also includes measures of } \\
\text { organizational climate, size, centralization, reward } \\
\text { structure, and job design [57] }\end{array}$ & $\begin{array}{l}{[57], \quad[114],} \\
{[122]}\end{array}$ \\
\hline Plan to proceed & $\begin{array}{l}\text { Plan for achieving goals, including objectives, } \\
\text { milestones, resources and costs [49] }\end{array}$ & $\begin{array}{l}{[16], \quad[49],} \\
{[75],[77]}\end{array}$ \\
\hline $\begin{array}{l}\text { Project functional } \\
\text { attributes }\end{array}$ & Capability, robustness, speed, cost, reliability & [123] \\
\hline Project management & $\begin{array}{l}\text { The relative priority of development objectives, } \\
\text { planned timings, communication, milestones, } \\
\text { project supervision [122] }\end{array}$ & $\begin{array}{l}{[86], \quad[103],} \\
{[107], \quad[114],} \\
{[122]}\end{array}$ \\
\hline Spiral development & $\begin{array}{l}\text { Things change. Smart teams operate in iterative } \\
\text { loops and build, test, obtain feedback, revise. [83] }\end{array}$ & [83] \\
\hline Team organization & $\begin{array}{l}\text { In terms of the team aspect: Are there people and } \\
\text { facilities available or not? In terms of the } \\
\text { organization is the project of high importance to } \\
\text { the senior management team. [14] }\end{array}$ & {$[14],[16]$} \\
\hline
\end{tabular}

\section{TABLE XIII}

Resourcing Selection Criteria

\begin{tabular}{|c|c|c|}
\hline Selection Criteria & Definition & Citation \\
\hline $\begin{array}{l}\text { Availability of } \\
\text { people and facilities }\end{array}$ & $\begin{array}{l}\text { This factor represents the compatibility of the } \\
\text { resource base of the firm with the requirements of } \\
\text { the project. It includes capital, manufacturing } \\
\text { facilities, and man-power requirements. [57] }\end{array}$ & $\begin{array}{lc}{[4],} & {[15],} \\
{[57],} & {[76],} \\
{[79],} & {[89],} \\
{[91],} & {[99],} \\
{[108],} & {[117]}\end{array}$ \\
\hline $\begin{array}{l}\text { Availability of raw } \\
\text { materials }\end{array}$ & $\begin{array}{l}\text { Assured availability of raw materials was defined } \\
\text { as a critical factor [61] }\end{array}$ & {$[4],[61]$} \\
\hline Constraints & Cost, schedule, personnel, technical [103] & [103] \\
\hline $\begin{array}{l}\text { Internal operating } \\
\text { factors }\end{array}$ & $\begin{array}{l}\text { Need to train employees, change in manufacturing } \\
\text { or service operations [4] }\end{array}$ & [4], [103] \\
\hline Level of dispersion & $\begin{array}{l}\text { Level of decentralization and the spatial } \\
\text { distribution of its staff [82] }\end{array}$ & $\begin{array}{l}{[82],} \\
{[121]}\end{array}$ \\
\hline organizational size & $\begin{array}{l}\text { Defined in terms of the organization's number of } \\
\text { full-time equivalent employees and by its revenue. } \\
\text { Size is an effective context factor because of } \\
\text { spreading of fixed costs, the potential for } \\
\text { specialization, and experience [82] }\end{array}$ & [82] \\
\hline $\begin{array}{l}\text { Supply chain } \\
\text { resilience }\end{array}$ & $\begin{array}{l}\text { How resilient is the supply chain to fluctuations in } \\
\text { resources [101] }\end{array}$ & {$[101]$} \\
\hline Technological skills & $\begin{array}{l}\text { Does the company have the capability and what is } \\
\text { the fit between processes required and resources } \\
\text { available [78] }\end{array}$ & $\begin{array}{l}{[4],} \\
{[78],} \\
{[89]}\end{array}$ \\
\hline
\end{tabular}

\footnotetext{
${ }^{1}$ Papers marked with an asterisk $(*)$ indicate those that are among the 46 identified articles
}

TABLE XIV

Legal and Regulatory Selection Criteria

\begin{tabular}{|c|c|c|}
\hline Selection Criteria & Definition & Citation \\
\hline $\begin{array}{l}\text { Legal and } \\
\text { regulatory issues }\end{array}$ & Understand key legal and regulatory issues [77] & $\begin{array}{l}{[4],[77],} \\
{[81],[94],} \\
{[104]}\end{array}$ \\
\hline Legal compliance & $\begin{array}{l}\text { Safety, health, environmental, operational } \\
\text { integrity [49] }\end{array}$ & {$[49],[64]$} \\
\hline Political impact & Positive or negative on a high-profile issue [15] & $\begin{array}{l}{[4],[15],} \\
{[76]}\end{array}$ \\
\hline Regulatory & $\begin{array}{l}\text { Are there any regulatory claims to settle and have } \\
\text { there been sufficient tests [14] }\end{array}$ & {$[14]$} \\
\hline $\begin{array}{l}\text { Risk time and } \\
\text { regulation }\end{array}$ & $\begin{array}{l}\text { All regulatory body risk criteria overlooking } \\
\text { industries should be taken into consideration [92] }\end{array}$ & [92] \\
\hline $\begin{array}{l}\text { Safety and working } \\
\text { environment }\end{array}$ & $\begin{array}{l}\text { Understand the need for safety in all operations } \\
\text { particularly the workplace [103] }\end{array}$ & [103] \\
\hline
\end{tabular}

\section{APPENDIX}

The following search strategy is used to extract the literature: (TITLE-ABS-KEY ("Decision making" OR "Decision theory" OR "Strategic decisions" ) AND TITLE-ABS-KEY ( "technology development process" OR "technology stage gate" OR "stage gate" OR "decision gate" OR "innovation management" OR "front end innovation" OR "fuzzy front end" OR "early stage innovation" OR "front end process" OR "new product introduction" OR "technolog* innovation process" OR "innovation funnel") AND TITLEABS-KEY ( criteria OR factors OR "success factors" OR "success criteria" OR "evaluation criteria" OR "evaluation factors" OR "selection criteria" OR "selection factors") ) AND ( LIMIT-TO ( DOCTYPE, "ar") OR LIMIT-TO ( DOCTYPE, "ip") ) AND ( LIMIT-TO ( LANGUAGE, "English" ))

\section{ACKNOWLEDGMENT}

The authors would like to acknowledge support of the Engineering and Physical Sciences Research Council (EPSRC). The authors would also like to thank Dr. Rob Phaal and the Strategic Technology and Innovation Management (STIM) 2018 consortium participants, for their helpful contributions and comments.

\section{REFERENCES ${ }^{1}$}

[1] H. W. Chang, C. C. Wei, and R. J. Lin, "A model for selecting product ideas in fuzzy front end," Concurr. Eng. Res. Appl., vol. 16, no. 2, pp. 121-128, 2008.

[2] A. P. A. P. Schulz, D. P. D. P. Clausing, E. Fricke, and H. Negele, "Development and integration of winning technologies as key to competitive advantage," Syst. Eng., vol. 3, no. 4, pp. 180-211, 2000.

[3] J. Fagerberg, D. Mowery, and R. Nelson, The Oxford Handbook of Innovation, 1st ed. Oxford: Oxford University Press, 2006. 
[4] C. Gardiner, "Evaluation and selection of coagulometers," Int. J. Lab. Hematol., vol. 32, no. November, pp. 1-85, 2010.

[5] T. Peters, J. Thiel, and C. L. Tucci, "Protecting growth options in dynamic markets: The role of strategic disclosure in integrated intellectual property strategies," Calif. Manage. Rev., vol. 55, no. 4, pp. 121-142, 2015.

[6] S. L. Jarvenpaa and L. Välikangas, “Opportunity creation in innovation networks: Interactive revealing practices," Calif. Manage. Rev., vol. 57, no. 1, pp. 6787, 2014.

[7] C. Horn and A. Brem, "Strategic directions on innovation management - a conceptual framework," Manag. Res. Rev., vol. 36, no. 10, pp. 939-954, 2013.

[8] J. Paasi, K. Valkokari, T. Rantala, H. Hytönen, S. Nystén-Haarala, and L. Huhtilainen, "Innovation management challenges of a system integrator in innovation networks," Int. J. Innov. Manag., vol. 14, no. 6, pp. 1047-1064, 2010.

[9] M. Bogers, "The open innovation paradox: Knowledge sharing and protection in R\&D collaborations," Eur. J. Innov. Manag., vol. 14, no. 1, pp. 93-117, 2011.

[10] European Commission, "Innovation Management and the Knowledge-Driven Economy," Eur. Comm. Dir. Enterp., vol. 4, no. 1, p. 164, 2004.

[11] Institute for Manufacturing Review, "The Next Production Revolution," Cambridge, UK, 2017.

[12] OECD, The Next Production Revolution: Implications for Governments and Business. OECD.

[13] G.-T. Jou and B. Yuan, "Utilizing a Novel Approach at the Fuzzy Front-End of New Product Development: A Case Study in a Flexible Fabric Supercapacitor," Sustainability, vol. 8, no. 8, p. 740, 2016.

[14] G. M. Ajamian and P. A. Koen, "Technology StageGate: a structured process for managing high-risk new technology projects," in The PDMA toolbook for new product development, New York: John Wiley \& Sons, 2002, pp. 267-295.

[15]* Cooper, "Managing technology development projects," Res. Technol. Manag., vol. 49, no. 1, pp. 23-31, 2006.

[16]* A. Khurana and S. R. Rosenthal, "Towards Holistic 'Front Ends' In New Product Development,' Journal of Product Innovation Management, vol. 15, no. 1. pp. 57-74, 1998.

[17] S. Ford, C. Aubert, and E. Ryckewaert, Reducing the risk in New Product Development: getting it right at the front end of innovation. 2016.

[18] P. A. Koen et al., "Providing Clarity and A Common Language to the Fuzzy Front End," Res. Technol. Manag., vol. 44, no. 2, pp. 46-55, 2001.

[19] M. Caetano, C. S. Araujo, D. C. Amaral, and F. M. Guerrini, "Open innovation and technology development process: the gap on partnership adoption from a case study perspective," Prod. Manag. Dev., vol. 9, no. 2, pp. 111-120, 2011.

[20] J. Kim and D. Wilemon, "Focusing the fuzzy frontend in new product development," R D Manag., vol.
32, no. 4, pp. 269-279, 2002.

[21] J. I. M. Halman, A. P. Hofer, and W. Van Vuuren, "Platform-driven development of product families: Linking theory with practice," J. Prod. Innov. Manag., vol. 20, no. 2, pp. 149-162, 2003.

[22] U. Högman and H. Johannesson, "Applying stage-gate processes to technology development - Experience from six hardware-oriented companies," J. Eng.

Technol. Manag. - JET-M, vol. 30, no. 3, pp. 264-287, 2013.

[23] D.-J. Kim and B. Kogut, "Technological Platforms and Diversification," Organ. Sci., vol. 7, no. 3, pp. 283-301, 1996.

[24] C. Prahalad and G. Hamel, "The Core Competence of the Corporation," Harv. Bus. Rev., vol. 68, no. 3, p. 79, 1990.

[25] L. Aristodemou, F. Tietze, E. O'Leary, and M. Shaw, "A Literature Review on Technology Development Process (TDP) Models," Cambridge, UK, 2019.

[26] K. Goffin and R. Mitchell, Innovation Management: Effective Strategy and Implementation. Palgrave Macmillan, 2016.

[27] R. G. Cooper, "Stage-Gate Systems: A New Tool for Managing New Products," Bus. Horiz., vol. 33, no. 3, pp. 44-54, 1990.

[28] E. W. Eldred and M. E. Mcgrath, "Commercializing New Technology I,” Res. Manag., vol. 40, no. 1, pp. 41-47, 1997.

[29] W. D. D. Sheasley, "Leading the Technology Development Process," Res. Technol. Manag., vol. 42, no. 2, pp. 130-153, 1999.

[30] W. D. D. Sheasley, "Taking an options approach to new technology development," Res. Technol. Manag., vol. 43, no. 6, pp. 37-43, 2000.

[31] K. B. Clark and S. C. Wheelwright, "Structuring the Development Funnel.," in Revolutionizing Product Development: Quantum Leaps in Speed, Efficiency, and Quality, 1992.

[32] P. O'Connor, "Implementing a Stage-Gate Process: A Multi-Company Perspective," J. Prod. Innov. Manag., 1994.

[33] R. Mcadam and S. Mccreedy, "A critical review of knowledge management models," Learn. Organ., 1999.

[34] U. R. Kulkarni, S. Ravindran, and R. Freeze, "A knowledge management success model: Theoretical development and empirical validation," J. Manag. Inf. Syst., 2006.

[35] B. Beresford and P. Sloper, Understanding the dynamics of decision-making and choice: A scoping study of key psychological theories to inform the design and analysis of the Panel, no. January. 2008.

[36] R. Sethi and Z. Iqbal, "Stage-gate Controls, Learning Failure, and Adverse Effect on Novel New Products," J. Mark., vol. 72, no. January, pp. 118-134, 2008.

[37] R. Mitchell, R. Phaal, and N. Athanassopoulou, "Scoring methods for evaluating and selecting early stage technology and innovation projects," 2018.

[38] L. Aristodemou and F. Tietze, "Technology Strategic Decision Making (SDM): an overview of decision 
theories, processes and methods," Cambridge, UK, 2019.

[39] A. H. Ahmed, H. Bwisa, R. Otieno, and K. Karanja, "Strategic Decision Making: Process, Models, and Theories," Bus. Manag. Strateg., vol. 5, no. 1, pp. 78104, 2014.

[40] J. Dewey, How we think, vol. 6. 1911.

[41] H. Mintzberg, D. Raisinghani, and A. Theoret, "The structure of 'unstructured' decision processes," Administrative science quarterly. pp. 246-275, 1976.

[42] H. A. Simon, "The New Science of Management Decision," Harvard Business Review, vol. 39. p. 104, 1961.

[43] H. a. Simon, "Decision Making: Rational, Nonrational, and Irrational," Educ. Adm. Q., vol. 29, no. 3, pp. 392-411, 1993.

[44] D. G. Ullman, "The Ideal Engineering Decision Support System," Retrieved March, vol. 10, p. 2009, 2002.

[45] R. M. Grant, Contemporary Strategy Analysis: Text \& Cases, vol. 8. 2012.

[46] F. W. Nickols, "Strategic Decision Making: Commitment to Strategic Action," 2015.

[47] R. Phaal, E. O’Sullivan, M. Routley, S. Ford, and D. Probert, "A framework for mapping industrial emergence," Technol. Forecast. Soc. Change, vol. 78, no. 2, pp. 217-230, 2011.

[48]* R. Phaal, M. Routley, N. Athanassopoulou, and D. Probert, "Charting Exploitation Strategies for Emerging Technology," Res. Manag., vol. 55, no. 2, pp. 34-42, 2012.

[49]* L. Y. Y. Cohen, P. W. W. Kamienski, and R. L. L. Espino, "Gate system focuses industrial basic research,” Res. Manag., vol. 41, no. 4, pp. 34-37, 1998.

[50]* R. Mitchell, R. Phaal, and N. Athanassopoulou, "Scoring methods for prioritizing and selecting innovation projects," PICMET 2014 - Portl. Int. Cent. Manag. Eng. Technol. Proc. Infrastruct. Serv. Integr., no. 2001, pp. 907-920, 2014.

[51] K. Edwards, R. G. Cooper, T. Vedsmand, and G. Nardelli, "Evaluating the Agile-Stage-Gate Hybrid Model: Experiences from three SME Manufacturing Firms," Int. J. Innov. Technol. Manag., 2019.

[52] R. G. Cooper and A. F. Sommer, "Agile-Stage-Gate for Manufacturers: Changing the Way New Products Are DevelopedIntegrating Agile project management methods into a Stage-Gate system offers both opportunities and challenges," Res. Technol. Manag., 2018.

[53] J. F. Tesch, A. S. Brillinger, and D. Bilgeri, "INTERNET of THINGS BUSINESS MODEL INNOVATION and the STAGE-GATE PROCESS: AN EXPLORATORY ANALYSIS," in International Journal of Innovation Management, 2017.

[54] G. Paré, M. C. Trudel, M. Jaana, and S. Kitsiou, "Synthesizing information systems knowledge: A typology of literature reviews," Inf. Manag., vol. 52, no. 2, pp. 183-199, 2015.

[55] P. Cronin, F. Ryan, and M. Coughlan, "Undertaking a literature review : a step-by-step approach," vol. 17, no. 1 , pp. $38-43,2008$.

[56] J. W. Creswell, Research Design: Qualitative, Quantitative, and Mixed Methods Approaches, 4th Editio. 2013.

[57]* M. M. Montoya-Weiss and R. Calantone, "Determinants of New Product Performance: A Review and Meta-Analysis," J. Prod. Innov. Manag., vol. 11, no. 5, pp. 397-417, 1994.

[58]* R. G. Cooper, "Perspective : The Stage-Gate idea to launch process - Update, what's new and nexgen systems," J. Prod. Innov. Manag., vol. 25, no. 3, pp. 213-232, 2008.

[59]* H. Ernst, "Success factors of new product development: A review of the empirical literature," Int. J. Manag. Rev., vol. 4, no. 1, pp. 1-40, 2002.

[60]* H. Ernst, "Patent information for strategic technology management," World Pat. Inf., vol. 25, no. 3, pp. 233242, 2003.

[61]* R. Balachandra and J. H. Friar, "Factors for success in R\&amp;D projects and new product innovation: a contextual framework," IEEE Trans. Eng. Manag., vol. 44, no. 3, pp. 276-287, 1997.

$[62]^{*} \quad$ A. Hidalgo and J. Albors, "Innovation management techniques and tools: a review from theory and practice," R\&D Manag., vol. 38, no. 2, pp. 113-127, 2008.

[63]* R. G. Cooper, S. J. Edgett, and E. J. Kleinschmidt, "Optimizing the Stage-Gate Process: What BestPractice Companies Do-I," Res. Manag., vol. 45, no. 5, pp. 21-27, 2002.

[64]* R. G. Cooper, S. J. Edgett, and E. J. Kleinschmidt, "Optimizing the Stage-Gate Process: What BestPractice Companies Do-II," Res. Manag., vol. 45, no. 6, pp. 43-49, 2002.

[65]* R. G. Cooper et al., "Benchmarking Best Npd Practices - Iii," Res. Manag., vol. 6308, no. January, pp. 43-55, 2004.

[66] D. B. Audretsch, E. E. Lehmann, and M. Wright, "Technology transfer in a global economy," $J$. Technol. Transf., vol. 39, no. 3, pp. 301-312, 2014.

[67] G. F. Nemet, "Demand-pull, technology-push, and government-led incentives for non-incremental technical change," Res. Policy, 2009.

[68] G. Di Stefano, A. Gambardella, and G. Verona, "Technology push and demand pull perspectives in innovation studies: Current findings and future research directions," Res. Policy, 2012.

[69] B. Crepon, E. Duguet, and J. Mairessec, "Research, Innovation And Productivi[Ty: An Econometric Analysis At The Firm Level," Econ. Innov. New Technol., 1998.

[70] A. Brem and K. I. Voigt, "Integration of market pull and technology push in the corporate front end and innovation management-Insights from the German software industry," Technovation, 2009.

[71] C. Herstatt and C. Lettl, "Management of "technology push' development projects," Int. J. Technol. Manag., 2004.

[72] J. Horbach, C. Rammer, and K. Rennings, 
"Determinants of eco-innovations by type of environmental impact - The role of regulatory push/pull, technology push and market pull," Ecol. Econ., 2012.

[73] R. G. Cooper, "Agile-Stage-Gate Hybrids," Res. Technol. Manag., vol. 59, no. 1, pp. 21-29, 2016.

[74] L. Aristodemou and F. Tietze, "A Literature Review on Technology Development Process ( TDP ) Models," 2018.

[75]* S. I. Petersen, J. E. Kim, and B. Borja de Mozota, "Comprehensive Capability Model for Managing Business Driven Innovation through the use of Design Quality Scorecards," Des. J., vol. 19, no. 2, pp. 339$351,2016$.

[76] R. G. Cooper, S. J. Edgett, and E. J. Kleinschmidt, "Portfolio management for new product development: Results of an industry practices study portfolio management for new product development : results of an industry practices study," $R \& D$ Manag. (Industrial Res. Institute, Inc.), vol. 13, no. 4, pp. 1-39, 2001.

[77] U. . D. of Energy, "Stage-Gate Innovation Management Guidelines: Managing risk through sturctured project decision-making," 2007.

[78]* R. G. Cooper and S. J. Edgett, "Developing a Product Innovation and Technology Strategy for Your Business," Res. Manag., vol. 53, no. 3, pp. 33-40, 2010.

[79]* J. Shin, S. Lee, and B. Yoon, "Identification and prioritisation of risk factors in R \&amp; D projects based on an R \&amp; D process model," Sustain., vol. 10, no. 4, pp. 1-18, 2018.

[80] G. Schewe, "Successful innovation management: An integrative perspective," J. Eng. Technol. Manag., vol. 11, no. 1, pp. 25-53, 1994.

[81]* V. Zemlickienè, A. Mačiulis, and M. Tvaronavičienè, "Factors impacting the commercial potential of technologies: expert approach," Technol. Econ. Dev. Econ., vol. 23, no. 2, pp. 410-427, 2017.

[82]* C. Busse and C. M. Wallenburg, "Firm-level innovation management at logistics service providers: An exploration," Int. J. Logist. Res. Appl., vol. 17, no. 5, pp. 396-419, 2014.

[83] R. G. Cooper, "Formula for Success in New Product Development," Stage-Gate Inc., no. April, 2006.

[84] S. J. Edgett, "Idea-to-Launch ( Stage - Gate ${ }^{\circledR}$ ) Model : An Overview," Stage-Gate Int., pp. 1-5, 2015.

[85] H. Ernst, "Success Factors of New Product Development: A Review of the Empirical Literature," Int. J. Manag. Rev., vol. 4, no. 1, pp. 1-40, 2002.

[86]* U. Högman and H. Johannesson, "Technology development and normative process models," 11th Int. Des. Conf. Des. 2010, pp. 265-274, 2010.

[87]* M. Martinsuo and J. Poskela, "Use of evaluation criteria and innovation performance in the front end of innovation," J. Prod. Innov. Manag., vol. 28, no. 6, pp. 896-914, 2011.

[88]* J. Oh, J. Yang, and S. Lee, "Managing uncertainty to improve decision-making in NPD portfolio management with a fuzzy expert system," Expert Syst.
Appl., vol. 39, no. 10, pp. 9868-9885, 2012.

[89]* C. F. Tsai and Z. Y. Chen, "Crossing the fuzzy front end chasm: Effective product project concept selection using a 2-tuple fuzzy linguistic approach," J. Intell. Fuzzy Syst., vol. 25, no. 3, pp. 755-770, 2013.

[90]* C. R. Davis, "Calculated risk," J. Chem. Heal. Saf., vol. 15 , no. 1, p. 36, 2008.

[91] S. J. Edgett and M. Jones, “Ten Tips for Successfully Implementing a Stage-Gate $\mathbb{B}$ Product Innovation Process," Work. Pap., pp. 1-11, 2013.

[92] A. Hultgren and A. Tantawi, "Front-End Idea Screening of Potential Radical Innovation in Large Firms," p. 112, 2014.

[93]* R. G. Cooper, "Where Are All the Breakthrough New Products?: Using Portfolio Management to Boost Innovation," Res. Manag., vol. 56, no. 5, pp. 25-33, 2013.

[94] U. Dornberger and A. Suvelza, Managing the Fuzzy Front-End of Innovation. 2012.

[95] R. G. Cooper, "Scorecards For Project Selection : Gates 1 \& 3 The Seven Forces Profiling Model," Inst. sutdy Bus. Mark., pp. 1-6, 2010.

[96] R. G. Cooper and S. J. Edgett, "Portfolio Management for New Products : Picking The Winners Portfolio Management for New Products Picking The Winners," 2014.

[97]* R. G. Cooper, "How Companies are Reinventing Their Idea-to-Launch Methodologies," Res. Manag., vol. 52, no. 2, pp. 47-57, 2009.

[98]* Å. Kastensson and C. Johansson, "Decision making in gates: Based on formal basis or gut feeling?," Int. J. Technol. Intell. Plan., vol. 7, no. 2, pp. 140-152, 2011.

[99]* M. G. de Oliveira, H. Rozenfeld, R. Phaal, and D. Probert, "Decision making at the front end of innovation: The hidden influence of knowledge and decision criteria," $R$ D Manag., vol. 45, no. 2, pp. 161-180, 2015.

$[100]^{*}$ N. Lakemond, G. Johansson, T. Magnusson, and K. Safsten, "Interfaces between technology development, product development and production: critical factors and a conceptual model," Int. J. Technol. Intell. Plan., vol. 3, no. 3, p. 317, 2007.

[101]* D. Kralisch et al., "The need for innovation management and decision guidance in sustainable process design," J. Clean. Prod., vol. 172, pp. 2374 2388, 2016.

[102]* I. M. Ilevbare, D. Probert, and R. Phaal, "Towards risk-aware roadmapping: Influencing factors and practical measures," Technovation, vol. 34, no. 8, pp. 399-409, 2014.

[103]* R. Kohli, J. Fishman, M. Field, and M. Hyatt, "Decision Gate Process for Assessment of a Technology Development Portfolio The Aerospace Corporation Civil and Commercial Operations Houston Programs 2525 Bay Area Blvd," pp. 1-22, 2018.

[104]* B. J. Paladino and P. Longsworth, "T „," Technology, no. December, 1995.

[105]* C. JOHANSSON, "Managing Uncertainty and Ambiguity in Gates: Decision Making in Aerospace 
Product Development," Int. J. Innov. Technol.

Manag., vol. 11, no. 02, p. 1450012, 2014.

[106] NASA, "Technology readiness levels," 2017. .

[107] H. Lercher, "Big Picture Innovation Model Handbook," 2016.

[108]* S. Singh Panesar and T. Markeset, "Development of a framework for industrial service innovation management and coordination," J. Qual. Maint. Eng., vol. 14, no. 2, pp. 177-193, 2008.

[109]* L. R. Soenksen and Y. Yazdi, "Stage-gate process for life sciences and medical innovation investment," Technovation, vol. 62-63, no. August 2016, pp. 1421, 2016.

[110] M. Maidique and B. Zirger, "A study of success and failure in product innovation: The case of the U.S. electronics industry," IEEE Trans. Eng. Manag, 1984.

[111] Investopedia, "Internal rate of return.".

[112] Investopedia, "Return on investment.".

[113] J. . Bard and R. Balachandra, "An interactive approach to $\mathrm{R} \& \mathrm{D}$ project selection and termination," IEEE Trans. Eng. Manag., vol. pp. Vol. 3, no. No. 3, pp. 139-146, 1988.

[114]* V. G. Alfaro-García, A. M. Gil-Lafuente, and G. G. Alfaro Calderón, "A fuzzy methodology for innovation management measurement," Kybernetes, vol. 46, no. 1, pp. 50-66, 2017.

[115] Investopedia, "Perceived value.".

[116]* U. De Brentani and S. E. Reid, "The fuzzy front-end of discontinuous innovation: Insights for research and management," J. Prod. Innov. Manag., vol. 29, no. 1, pp. 70-87, 2012.

[117]* P. A. Koen, H. M. J. Bertels, and E. J. Kleinschmidt, "Managing the Front End of Innovation - Part I," Res. Technol. Manag., vol. 57, no. 3, pp. 34-43, 2014.

[118]* C. I. Kerr, L. Mortara, R. Phaal, and D. R. Probert, "A conceptual model for technology intelligence," Int. J. Technol. Intell. Plan., vol. 2, no. 1, pp. 73-93, 2006.

[119]* R. G. Cooper, "What's Next?: After Stage-Gate," Res. Manag., vol. 57, no. 1, pp. 20-31, 2014.

[120]* A. Riel, M. Neumann, and S. Tichkiewitch, "Structuring the early fuzzy front-end to manage ideation for new product development," CIRP Ann. Manuf. Technol., vol. 62, no. 1, pp. 107-110, 2013.

[121]* D. Jugend, S. L. da Silva, P. C. Oprime, and M. L. Pimenta, "Organizational issues for integration of high-technology in new product development: Framework proposal and case studies in Brazilian companies," Innov. Manag. Policy Pract., vol. 17, no. 2, pp. 217-231, 2015.

[122]* J. M. Zabala-iturriagagoitia, "Management \& Innovation New Product Development in Traditional Industries : Decision-Making Revised," vol. 7, no. 1, 2012.

[123]* M. Collins and L. Williams, "A three-stage filter for effective technology selection," Res. Technol. Manag., 2014.

\section{AUTHORS}

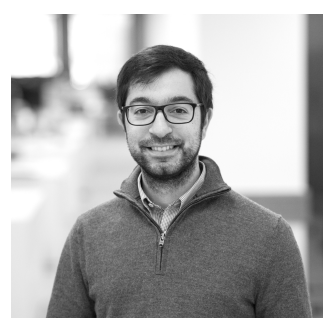

Leonidas Aristodemou is a doctoral researcher at the University of Cambridge, Department of Engineering, Institute for Manufacturing, Centre for Technology Management. He is also an enrichment scholar at The Alan Turing Institute, in London, UK. He is supervised by Dr. Frank Tietze and advised by Prof. Tim Minshall. He obtained a Master's in engineering (MEng) with Distinction, and a Bachelor of Arts (BA) in Engineering, from the University of Cambridge. He went on to work for Procter and Gamble in the field of Technology and Operations Management. He is an executive board member of the Cambridge University Engineers Association and a member of St. Edmund's College

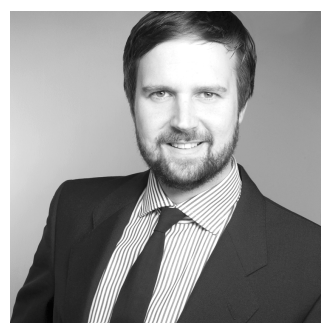

Dr. Frank Tietze is a Lecturer in Technology and Innovation Management at University of Cambridge, Institute for Manufacturing. Within the Centre for Technology Management (CTM), he leads the Innovation and Intellectual Property Management (IIPM) Lab. He holds a doctoral degree in economics and social sciences from Hamburg University of Technology, in Germany. He is departmental editor of IEEE Transactions on Engineering Management, editorial board member of World Patent Information, editorial review board member of LES Nouvelles, and the editor for the CTM working paper series.

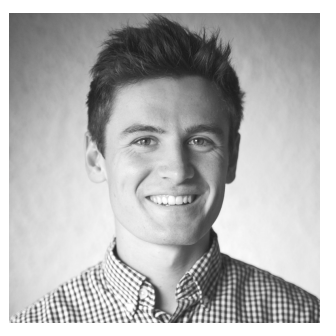

Matthew Shaw is an associate consultant in Teneo Consulting. He obtained a Master's in engineering (MEng) with Distinction, and a Bachelor of Arts (BA) in Engineering, from the University of Cambridge. He completed his Master thesis under the supervision of Dr. Frank Tietze and Leonidas Aristodemou at the Centre for Technology Management, Institute for Manufacturing, Department of Engineering, University of Cambridge. 